\title{
Impact of forests on net national emissions of carbon dioxide in west Europe
}

Kauppi, P.E.

Kluwer

1993

Kauppi, P.E. and Tomppo, E. 1993. Impact of forests on net national emissions of carbon dioxide in west Europe. Water, Air, and Soil Pollution 70: 187-196.

http://hdl.handle.net/1975/301

Downloaded from Helda, University of Helsinki institutional repository.

This is an electronic reprint of the original article.

This reprint may differ from the original in pagination and typographic detail.

Please cite the original version. 


\title{
IMPACT OF FORESTS ON NET NATIONAL EMISSIONS OF \\ CARBON DIOXIDE IN WEST EUROPE
}

\author{
P.E. KAUPPI and E. TOMPPO \\ Finnish Forest Research Institute, Unioninkatu 40 A, SF-00170 Helsinki, \\ Finland
}

\begin{abstract}
The amount of forest biomass increased and thereby reduced the net national emissions of $\mathrm{CO}_{2}$ in Europe, in some countries more than in others. Estimates of the annual $\mathrm{C}$ fluxes through forests in 17 west European countries are presented, based on recent statistics. The flux in each country is subdivided into components referring to removal, change in the remaining growing stock, and detritus formation. The relative contribution of forests to the national $\mathrm{C}$ budget varied by two orders of magnitude between the upper extremes (Sweden and Finland) and the lower extremes (Netherlands, Belgium and the UK). Such large differences between countries must have an impact on policies and strategies for controling the net $\mathrm{C}$ emissions. Because the capacity of forests to carry biomass is limited, the net flux of $\mathrm{C}$ from the atmosphere into the forests is expected to decrease. Afforestation and improved management of the removed forest biomass could compensate for this development.
\end{abstract}

\section{Introduction}

The United Nations Climate Convention, in order "...to achieve stabilization of greenhouse gas concentrations in the atmosphere ... at a level that would prevent dangerous anthropogenic interference with the climate system", engages all Parties to formulate national and, where appropriate, regional programs including measures to mitigate climate change (UN Framework Convention..., 1992). Forestry affects the fluxes of $\mathrm{C}$ between the atmosphere, vegetation, soils and forest products, and is a potential agent both in controlling and in contributing to national net emissions. Forestry measures, on a country-by-country basis, could be developed to contribute to the policies of meeting national emission goals. Both direct and indirect evidence suggests that boreal and temperate forests have acted as a stronger sink of atmospheric $\mathrm{C}$ than was estimated earlier (Sedjo, 1992; Tans et al, 1990). Detailed analyses have been carried out for Canada, indicating net transfer of $\mathrm{C}$ from the atmosphere into forest ecosystems and forest products (Apps and Kurz, 1991; Kurz and Apps, this volume). In Europe, forest biomass has increased and additional $\mathrm{C}$ has been sequestered in forest products (Kauppi et al, 1992). However, tropical deforestation has continued at a rapid rate (Tolba et al, 1992) and the World's forests are currently estimated to be a source term in the global C budget (Sedjo, 1992). 
When old-growth forest is cleared and converted into forest which is managed for maximum sustained yield, standing biomass is reduced by about two thirds (Cooper, 1983). Although such conversion and biomass development has taken place in many regions, as in north western U.S. (Harmon et al, 1990), biomass development has been the reverse in other areas. Large parts of the old-growth forests in central Europe were cleared in the Middle Ages (Kandler, 1992) and almost all of the contemporary harvest is from secondary forests. New statistics from ECE/FAO are used in this paper to analyze $\mathrm{C}$ fluxes and the capacity for $\mathrm{C}$ sequestration in forestry on a country by country basis (The Forest Resources of the Temperate Zone..., 1992). The statistics refer to the mid and late 1980s.

The focus of this paper is on five member countries of the European Free Trade Association (EFTA): Austria, Finland, Norway, Sweden and Switzerland; and on the 12 member countries of the European Community (EC): Belgium, Denmark, France, Germany, Greece, Ireland, Italy, Luxenbourg, Netherlands, Portugal, Spain and the United Kingdom. The total forest resources of these 17 countries expanded in the 1980s in terms of both the growing stock and the area of forest and other wooded land (The Forest Resources of the Temperate Zone..., 1992; and The Forest Resources of the ECE Region..., 1985).

\section{Carbon Fluxes and Storages}

We denote the total annual flux of $\mathrm{C}$ in forestry as $C_{f r}$ (Figure1) and divide it into three flux components: 1) $\mathrm{C}$ in removal, $\left.C_{r m}, 2\right) \mathrm{C}$ in detritus formation, $C_{d t}$, and 3) $\mathrm{C}$ in the net change of living biomass, $C_{s t}$ (the storage rate). The description of fluxes and storages is similar to that presented by Apps and Kurz (1991) and Dewar and Cannell (1992).

Statistics on gross annual increment (The Forest Resources of the Temperate Zone..., 1992) were converted into estimates of the total annual flux of $\mathrm{C}$ in forestry, $C_{f r}$, by accounting for branches, roots and foliage, and for the $\mathrm{C}$ content in biomass. The lower and upper estimates of the biomass in roots, branches and foliage were obtained by multiplying stemwood biomass by 0.4 and 1.1, respectively (Brown and Lugo, 1984). Bulk density of $400 \mathrm{~g}$ dry matter per liter wood, and a C content of $50 \%$ were assumed (Hakkila, 1989). Carbon in removal, $C_{r m}$, was calculated in the same way from the statistics (The Forest Resources of the Temperate Zone..., 1992), taking only stemwood (overbark) into account. Carbon in the net storage of biomass, $C_{s t}$, was estimated as the difference between net annual increment and felling, in terms of whole tree biomass. Carbon in detritus formation, $C_{d t}$, was calculated by subtracting $C_{s t}$ and $C_{r m}$ from the total flux, $C_{f r}$.

The net change of biomass, $C_{s t}$, can be negative as a result of wild fire, logging, deforestation, pollution damage, etc. The net change is positive when biomass builds up, i.e, when increment exceeds the sum of losses and removals. Net changes of the $\mathrm{C}$ pools in detritus and in products were not included in this analysis but have been estimated in a similar study for Canada (Apps and Kurz, 1991) and the UK (Dewar and Cannell, 1992). 


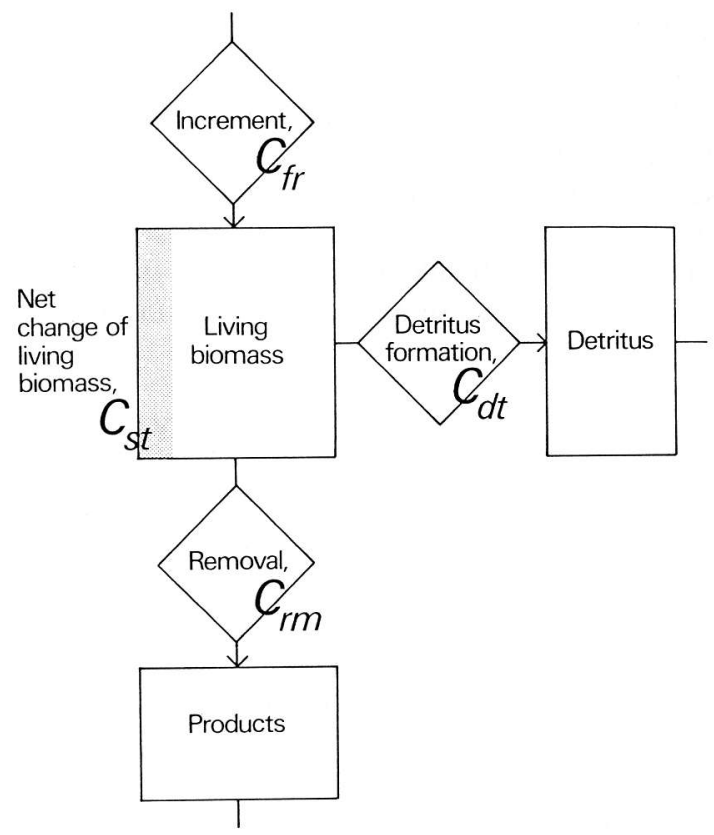

Fig 1. Fluxes of carbon in forestry. The total forestry flux $\left(C_{f r}\right)$ is divided into three compoments: 1) Removal $\left.\left(C_{r m}\right), 2\right)$ Detritus formation $\left(C_{d c}\right)$, and 3) Net change of living biomass $\left(C_{S t}\right)$.

\subsection{CARBON IN REMOVAL $\left(\mathrm{C}_{\mathrm{rm}}\right)$}

The statistics on wood removal indicate a harvest of 143 and $155 \times 10^{6} \mathrm{~m}^{3}$ in EFTA and EC, respectively. This amount of wood, used for various products, contains a total of 60 $\operatorname{Tg} C\left(\mathrm{Tg}=10^{12} \mathrm{~g}\right)$. The fate and the decay rate of the different products are less well known. Soft products like newsprint have a short life span, whereas construction wood can store carbon for decades or centuries. Carbon in soft products can also remain intact if disposed of in landfill sites.

\subsection{CARBON IN DETRITUS FORMATION $\left(\mathrm{C}_{\mathrm{dt}}\right)$}

The removal of $60 \mathrm{Tg} \mathrm{C}$ in stemwood implies an annual transfer of 24 to $66 \mathrm{Tg} \mathrm{C}$ from the pool of living biomass into the detritus pool in the form of the roots, branches and foliage of felled trees. This estimate refers to the whole region (EFTA+EC). Natural losses and stem residues account for additional detritus fluxes, and the total $\mathrm{C}$ flux in detritus formation, $C_{d t}$, was estimated at 31 to $76 \mathrm{Tg}$. An additional detritus flux, not included in this estimate, is due to the annual turnover of foliage and fine roots. 


\subsection{CARBON IN THE NET STORAGE OF LIVING BIOMASS $\left(\mathrm{C}_{\mathrm{st}}\right)$}

Felling comprised a modest 72 and $68 \%$ of the net annual increment in EFTA and EC, respectively (The Forest Resources of the Temperate Zone..., 1992). A positive net change of living biomass was reported by each of the 17 countries; the gross annual increment exceeded the sum of natural losses, removal and harvest residues. The growing stock increased annually in the late 1980 s by 68 and $72 \times 10^{6} \mathrm{~m}^{3}$ in EFTA and EC, respectively. This corresponds to a net increase of 39 to $58 \mathrm{Tg} \mathrm{C}$ in living biomass in EFTA+EC.

\subsection{TOTAL CARBON FLUX IN FORESTS AND FORESTRY $\left(\mathrm{C}_{\mathrm{fr}}\right)$}

The three subfluxes within forestry, as described in Figure 1, were of the same order of magnitude in many of the European countries (Table 1). However, there ware large differences between countries in terms of the impact of forest on net national emissions. Forest is an important component of the national $\mathrm{C}$ budget of EFTA countries, in fact decisive in Sweden and Finland, but less important in the EC being almost negligible in countries like Belgium, the Netherlands and the UK. The relative contribution of forests to $\mathrm{C}$ budget was an order of magnitude larger in EFTA than in the EC.

The total flux of $C\left(C_{f r}\right)$ was 62 to $94 \mathrm{Tg}$ in EFTA, about the same as the emissions of $C$ from the combustion of fossil fuels ( $C_{f o s}$ as documented in IEA/OECD, 1992). EFTA countries export large quantities of wood products, whereas the EC countries are net importers. It can be estimated that a flux of 5 to $10 \mathrm{Tg} \mathrm{C}-$ a fraction of the removal flux - enters from EFTA to the European Community. Forest products from other parts of the world are also imported to the $\mathrm{EC}$, where the total $\mathrm{C}$ flux in forest sector is thus larger than the domestic flux estimated in Table 1.

\section{Discussion}

\subsection{UNCERTAINTY OF THE ESTIMATES}

The accuracy and precision of forest statistics vary considerably from country to country. Applying well established methods (Lindeberg, 1923; Langsaeter, 1926; Loetsch et al, 1973), growing stock and annual increment were estimated over large areas, e.g. on a national scale. Temporary sampling plots were located in a grid covering the study area, and accurate measurements were made on those plots. Currently, at least one national forest inventory has been carried out in most European countries, though increment measurements have not been taken in all inventories.

Permanent sample plots have allowed reliable estimates of mortality (natural loss) to be made. Both temporary and permanent plots have been included in inventories, e.g. in Austria, Finland, Sweden and Switzerland. The use of sampling with partial replacement (Ware and Cunia, 1960) has thus been possible.

As national inventories have provided information relating to large areas, another inventory system, standwise inventory, has been maintained in many European countries for operational management of forestry. This system is costly and involves subjective 
Table 1. Annual fluxes of carbon in removal $\left(C_{r m}\right)$, into detritus $\left(C_{d t}\right)$, into living biomass $\left(C_{s t}\right)$, within forestry in total $\left(C_{f r}\right)$, and in energy-related $\mathrm{CO}_{2}$ emissions $\left(C_{f o s}\right)$.

\begin{tabular}{|c|c|c|c|c|c|}
\hline Country/Region & $C_{r m}$ & $C_{d t}$ & $\begin{array}{c}C_{s t} \\
10^{12} \mathrm{~g} \mathrm{a}^{-1}\end{array}$ & $C_{f r}$ & $C_{f o s}$ \\
\hline $\begin{array}{l}\text { Austria } \\
\text { Finland } \\
\text { Norway }\end{array}$ & $\begin{array}{c}3.3 \\
10.4 \\
2.4\end{array}$ & $\begin{array}{c}1.5-4.0 \\
5.6-13.6 \\
1.3-3.2\end{array}$ & $\begin{array}{l}1.9-2.8 \\
4.5-6.7 \\
1.9-2.8\end{array}$ & $\begin{array}{c}6.7-10.1 \\
20.5-30.7 \\
5.6-8.4\end{array}$ & $\begin{array}{c}15.6 \\
16.0 \\
8.7\end{array}$ \\
\hline $\begin{array}{l}\text { Sweden } \\
\text { Switzerland }\end{array}$ & $\begin{array}{c}11.4 \\
1.1\end{array}$ & $\begin{array}{c}5.8-14.4 \\
0.5-1.3\end{array}$ & $\begin{array}{c}10.6-15.9 \\
0.2-0.3\end{array}$ & $\begin{array}{c}27.8-41.7 \\
1.8-2.7\end{array}$ & $\begin{array}{l}15.1 \\
12.1\end{array}$ \\
\hline EFTA & 29 & $15-36$ & $19-28$ & $62-94$ & 68 \\
\hline $\begin{array}{l}\text { Belgium } \\
\text { Denmark } \\
\text { France }\end{array}$ & $\begin{array}{c}0.7^{*} \\
0.4 \\
10.4\end{array}$ & $\begin{array}{c}0.3-0.8^{*} \\
0.3-0.6 \\
3.9-11.1\end{array}$ & $\begin{array}{l}0.3-0.5^{*} \\
0.3-0.5 \\
5.5-8.3\end{array}$ & $\begin{array}{c}1.3-2.0^{*} \\
1.0-1.6 \\
19.8-29.7\end{array}$ & $\begin{array}{c}33.8 \\
15.3 \\
104.7\end{array}$ \\
\hline $\begin{array}{l}\text { Germany } \\
\text { Greece } \\
\text { Ireland }\end{array}$ & $\begin{array}{l}9.4^{*} \\
0.6 \\
0.3\end{array}$ & $\begin{array}{c}5.4-12.9^{*} \\
0.7-1.2 \\
0.1-0.3\end{array}$ & $\begin{array}{l}4.9-7.3^{*} \\
0.1 \\
0.5-0.8\end{array}$ & $\begin{array}{c}19.7-29.6^{*} \\
1.3-2.0 \\
0.9-1.4\end{array}$ & $\begin{array}{c}283.4 \\
22.1 \\
9.0\end{array}$ \\
\hline $\begin{array}{l}\text { Italy } \\
\text { Luxenbourg } \\
\text { Netherlands }\end{array}$ & $\begin{array}{c}1.6^{*} \\
0.06^{*} \\
0.3\end{array}$ & $\begin{array}{c}1.2-2.6^{*} \\
0.05-0.1^{*} \\
0.09-0.3\end{array}$ & $\begin{array}{c}2.6-3.9^{*} \\
0.1^{*} \\
0.3-0.5\end{array}$ & $\begin{array}{c}5.4-8.1^{*} \\
0.2-0.3^{*} \\
0.7-1.1\end{array}$ & $\begin{array}{l}112.1 \\
2.8 \\
49.9\end{array}$ \\
\hline $\begin{array}{l}\text { Portugal } \\
\text { Spain } \\
\text { United Kingdom }\end{array}$ & $\begin{array}{l}2.2 \\
3.7 \\
1.5\end{array}$ & $\begin{array}{l}0.9-2.5 \\
2.2-5.2 \\
0.9-2.0\end{array}$ & $\begin{array}{l}0.3-0.4 \\
4.1-6.3 \\
0.8-1.2\end{array}$ & $\begin{array}{c}3.3-5.0 \\
10.1-15.1 \\
3.1-4.7\end{array}$ & $\begin{array}{c}11.7 \\
61.2 \\
160.6\end{array}$ \\
\hline $\mathrm{EC}$ & 31 & $16-40$ & $20-30$ & $67-100$ & 870 \\
\hline $\mathrm{EFTA}+\mathrm{EC}$ & 60 & $31-76$ & $39-58$ & $130-194$ & 930 \\
\hline
\end{tabular}

\footnotetext{
* Gross annual increment was estimated comparable to that reported in the neighbouring countries in cases when data were missing.
} 
assessment and field work which can result in large errors when the data are aggregated to describe large areas. New technology has recently been introduced in order to combine the two inventory systems and to provide both statistically reliable data and relevant information within small regions. The Finnish National Forest Inventory, for example, employs satellite image data and digital map data in addition to ground measurements on sample plots (Tomppo, 1991). Figure 2 shows an example of an output thematic map. The technology, including space- and airborne remote sensing, both in optical and microwave regions, is developing rapidly and also shows promise for estimating $\mathrm{C}$ storages. Forthcoming, more precise and accurate surveys may alter some of the figures in Table 1, notably those for countries like Germany and Italy, where the estimates of gross annual increment have not been derived from a statistically representative sample.

Soil C, a large reservoir, was assumed stable in this analysis. In other words, it was assumed that the decomposition of organic matter in the humus layer and in soil fully compensated for the formation of dead organic matter. Lugo (1992) has criticized such steady state assumptions. In Europe, it is possible that the pool of $\mathrm{C}$ in forest soils is increasing rather than decreasing. Although prescribed burning, silvicultural site preparation and drainage of peatlands (Gorham, 1991) tend to decrease C storage in soils, other and probably more powerful trends, such as improved fire control and the reduction of cattle grazing in forest have the opposite effect. Differences can occur between countries in terms of changes of $\mathrm{C}$ pool in soils. In Finland, for example, a large program has been carried out to drain peatlands for timber production. Decomposition of organic soil on drained peatlands can have a significant effect on net national $\mathrm{CO}_{2}$ emissions (however, see Laine et al, 1992).

\subsection{POLICY IMPLICATIONS}

Given the work of international programs and conferences such as IPCC and UNCED, the concept of net national emisssions is becoming increasingly important in developing and evaluating policy alternatives. Net national emissions determine the impact of each individual country on the concentration of $\mathrm{CO}_{2}$ in the atmosphere. Each country is committed according to the Climate Convention to report and periodically update the "emissions by sources and removals by sinks". National emission targets are negotiated. Each country has the freedom to choose cost-efficient strategies for emission control and to take into account the country-specific infrastructure affecting "emissions and removals".

Using forests to sequester carbon dioxide from the atmosphere has long been discussed (Dyson, 1977). In western Europe in the 1980s, the total annual flux of C in forests and forest products was 14 to $20 \%$ of the $\mathrm{C}$ flux from the use of fossil fuels. Although forests affect the $\mathrm{C}$ budget of the region, measures within the forest sector cannot be used as the main solution eventually to reduce $\mathrm{C}$ emissions. The $\mathrm{C}$ flux through forests is simply too small. However, in Sweden and Finland, taken together, the C flux within the forest sector is larger than the flux from fossil fuels by a factor of 1.6 to 2.3. In the Netherlands and the UK the domestic C flux within forest sector is only 2 to $3 \%$ of the $\mathrm{C}$ releases from fossil fuels. The potential of the forest sector to affect the net national emissions of $\mathrm{CO}_{2}$ thus varies by as much as two orders of magnitute between countries in industrial western Europe. Such differences between countries can have profound impacts on national strategies for controling $\mathrm{CO}_{2}$ emisssions. 


\section{CENTRAL-FINLAND, VOLUME, M3/HA}

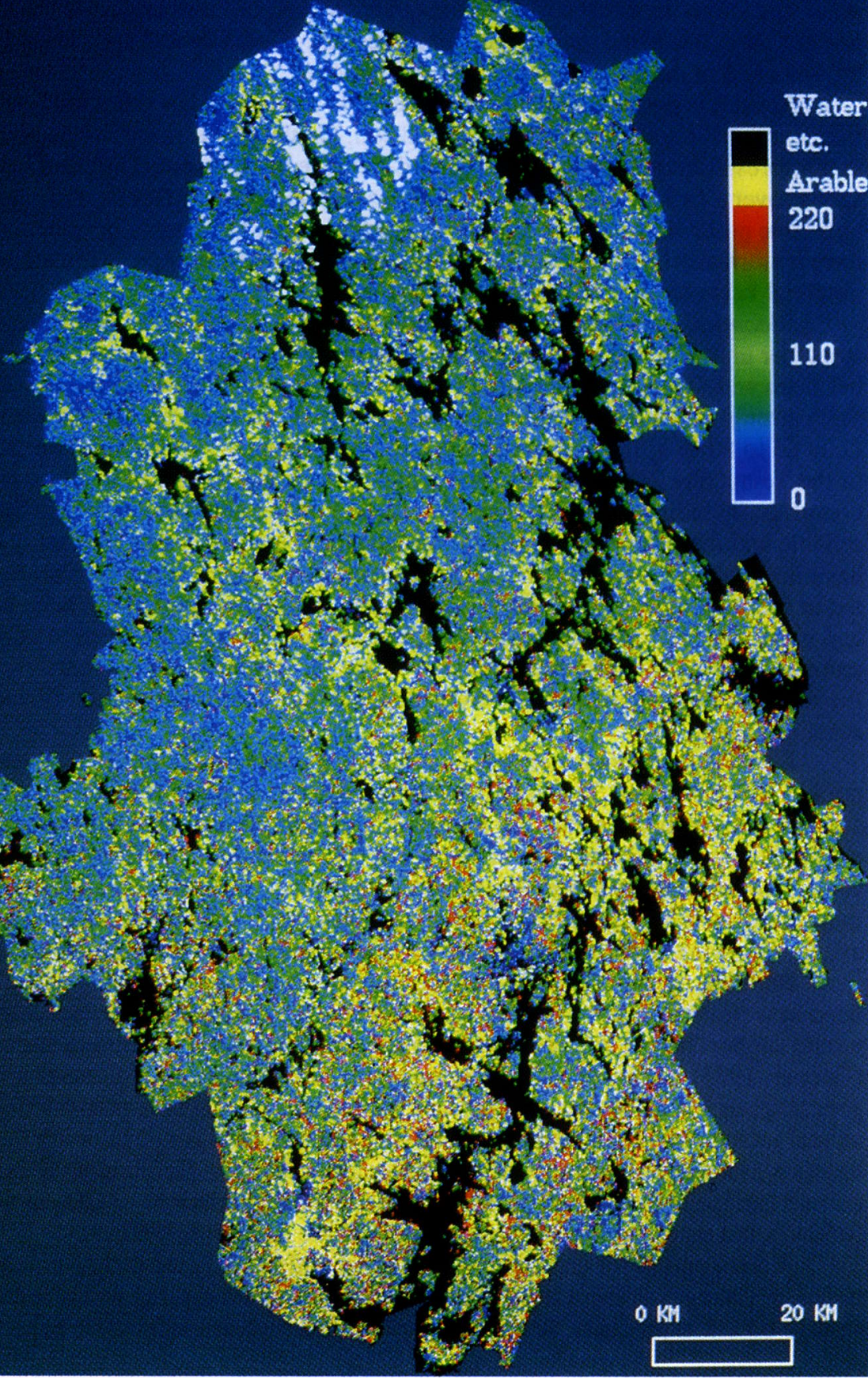

Fig 2. Thematic map of forest inventory results. 
Many forestry policies are available for controlling the net national emissions of $\mathrm{CO}_{2}$. Fire control, drainage, site preparation practices, and game management affect $\mathrm{C}$ pools and fluxes in forest soils, but the quantification of these effects is difficult at the present time. It is easier to evaluate measures that affect $C$ pools and fluxes in living biomass and in the biomass harvested and removed.

First, it is possible to plant new forests on agricultural or other land, which would increase the $\mathrm{C}$ pool in living biomass and soil. On the global scale, it has been calculated that afforestation of $4.56 \times 10^{6} \mathrm{~km}^{2}$ could stabilize the $\mathrm{CO}_{2}$ concentration in the atmosphere over a time period of several decades (Sedjo, 1989). Afforestation can be an attractive policy in central and southern Europe where large areas of potential forest land have historically been cleared for agriculture. In northern Europe, afforestation has less potential because most of the land is forest anyway.

Secondly, growing stock can be increased on a given area of forest land. Growing stock per unit of forest land has increased in most industrial countries. This development has been widely ignored although in many countries it has affected the national $\mathrm{C}$ budget more strongly than afforestation. Underlying factor has been the low harvesting rate. Only 65 to $80 \%$ of the net annual increment has been harvested (The Forest Resources of the Temperate Zone..., 1992). The growing stock has increased in all west European countries, including countries such as Austria, Finland and Sweden where the data are reliable and there has been very little afforestation. Natural losses (mortality of trees) have been insignificant, and the difference between increment and harvest has accumulated in forests almost entirely as living biomass. This development has been unplanned and undesired. The intention in Austria, Finland and Sweden has been to maintain the amount of living biomass approximately at the present level, and to match harvest with the net increment. However, low wood demand has prevented the full utilization of the sustained yield.

It would be possible actively to stimulate the trend and further to increase the $\mathrm{C}$ pool in living biomass. This policy could be effective in areas where the present growing stock is low compared to the site potential. For example, relatively short rotation cycles are applied in the existing plantations in the UK and in Ireland. There is potential in these forests for building up the growing stock. In contrast, there is only a small potential of increasing the growing stock per hectare of forest land in Switzerland and Germany. The average growing stock in these countries is approaching the potential upper limit.

Building up the $\mathrm{C}$ pool of existing forests is beneficial in certain cases. There is a need in western Europe to reserve new forest areas for nature protection. Such areas would support higher biomass levels than areas managed for maximum sustained yield (Cooper, 1983). However, it is questionable to aim at increasing biomass levels as a general policy in all forests. An increase of standing stock will lead to a reduction of net annual increment in the long term, implying less potential for developing the use of biomass as a renewable source of raw material and energy. Building up living biomass in current European forests can decrease the national net emissions of $\mathrm{CO}_{2}$ in the short term $(<50 \mathrm{yr})$, but tends to increase the emissions in the long term ( $>50 \mathrm{yr})$.

A third option for controling net national emissions is the management of removed biomass. Changes in favor of long-lasting products and recycling would increase the $\mathrm{C}$ storage bound in products. Bioenergy applications such as using waste paper to substitute 
fossil fuels can contribute to a decrease of net $\mathrm{CO}_{2}$ emissions. The disposal of waste paper and other used products in landfill sites or in abandoned mines can delay or even prevent decomposition and contribute to $\mathrm{C}$ sequestration. Due consideration is needed for the potential increase of $\mathrm{NH}_{3}$ emissions.

Proper management of the removed biomass should be recognized as an important policy alternative for controling the net national emissions of $\mathrm{CO}_{2}$. In EFTA+EC, the present annual $\mathrm{C}$ flux associated with timber removal is $60 \mathrm{Tg} \mathrm{C} \mathrm{yr}^{-1}$. It determines the present upper limit which can be sequestered with the management of the removed biomass. A theoretical upper limit is higher. The present harvest rate has been low compared to the sustainable yield. New plantations, in addition to increasing the $\mathrm{C}$ pool in biomass and soils, would add to the removal. Assuming an increase of forest area by 5 to $30 \%$, slight improvement of the present average yield, and the full use of sustained yield, the upper limit in EFTA+EC is 100 to $200 \mathrm{Tg} \mathrm{yr}^{-1}$ of sequestering $\mathrm{C}$ by means of the management of removed biomass. This is 10 to $20 \%$ of the present emisions from fossil fuels.

A combination of afforestation, forest protection and the managemant of removed biomass could be developed to control net national emissions of $\mathrm{CO}_{2}$. According to our estimate, the sustainable potential to be achieved ranges between 150 and $250 \mathrm{Tg} \mathrm{C}$ annually in western Europe in the long term. This is higher than the present sequestration rate by a factor of 2 to 4 . The management of the removed biomass would account for more than half of the estimated potential. An eventual climate change, the $\mathrm{CO}_{2}$ stimulation of phosysthesis and growth, and other factors not included in this analysis generate large uncertainty to these projections.

The accumulation of living biomass accounts for a sequestration of 39 to $58 \mathrm{Tg} \mathrm{C}$ $\mathrm{yr}^{-1}$ in western Europe at the present time. This flux is mainly due to the build-up of biomass in existing middle-aged and mature stands. Accumulation of biomass can continue temporarily but is unsustainable in the long term. Therefore, this sink is expected to disappear. Afforestation and controlling the $\mathrm{C}$ flux associated with removal could substitute this temporary sink and have a more long-term impact.

\section{References}

Apps, M. and Kurz, W.: 1991, World Resource Review 3, 333.

Brown, S. and Lugo, A.E.: 1984, Science 223, 1290.

Cooper, C.F.: 1983, Can. J. For. Res. 13, 155.

Dewar, R.C. and Cannell,M.G.R.: 1992, Tree Physiol. 11, 49.

Dyson, F.J.: 1977, Energy 2, 287.

Gorham, E.: 1991, Ecological Applications 1, 182.

Hakkila, P.: 1989,Utilization of Residual Forest Biomass, Springer-Verlag, Berlin, Heidelberg, New York. 
Harmon, M.E., Ferrell, W.K. and Franklin J.F.: 1990, Science 247, 699.

IEA/OECD Energy and the Environment Series: 1992, Climate Change Policy Initiatives.

Kandler, O.: 1992. Environmental Toxicology and Chemistry 11, 1077.

Kauppi, P.E., Mielikäinen, and Kuusela, K.: 1992, Science 256, 70.

Kurz, W. and Apps, M.: 1993, This volume.

Laine, J, Wasander, H. and Puhalainen, A.: 1992, Effect of Forest Drainage on the Carbon Balance of Mire Ecosystems, in :Proceedings of the 9th International Peat Congress.

Langsaeter, A.: 1926, Medd. Norske Skogsforsöksv. $27,5$.

Lindeberg, J.: 1923, Acta Forestalia Fennica 25, 1.

Loetsch, F., Zöhrer, F. and Haller, K.E.: 1973, Forest Inventory, BLV Verlagsgesellschaft, München, Bern, Wien, vol. 1-2.

Lugo, A.E.: 1992, The Search for Carbon Sinks in the Tropics, in Wisniewski J. and Lugo A.E. (eds), Natural Sinks of CO2, Kluwer Academic Publishers, pp. 3-9.

Sedjo, R.A.: 1989, J. Forestry 87 (7), 12.

Sedjo, R.A.: 1992, Ambio 21, 274.

Tans, P.P., Fung, I.Y., and Takahashi, T.: 1990, Science 247, 1431.

Tolba, M.K., El-Kholy, O.A., El-Hinnawi. E., Holdgate, M.W., McMichael, D.F., and Munn, R.E. (eds) : 1992, The World Environment 1972-1992. UNEP Chapman \& Hall, London.

Tomppo, E.: 1991, Int. Archives of Photogrammetry and Remote Sensing 28, 419.

The Forest Resources of the Temperate Zones, Main Findings of the UN-ECE/FAO 1990 Forest Resource Assessment, ECE/TIM/60, UN Publications Sales No. E.92.II.E.23 (1992); The Forest Resources of the Temperate Zones, The UN- ECE/FAO 1990 Forest Resource Assessment, Vol 1, General Forest Resource Information, ECE/TIM/62, UN Publication Sales No. E.92.II.E.27 (1992).

The Forest Resources of the ECE region (Europe, the USSR, North America), UN-FAO/ ECE, ECE/TIM/27 (1985).

UN Framework Convention on Climate Change. United Nations (1992).

Ware, K.D. and Cunia, T.: 1960, For. Science-Monograph 3, 1.

\section{Acknowledgments:}

We thank J. Alcamo, P. Hari, K. Kuusela, P. Nöjd and P. Stenberg for comments, and M. $\mathrm{S}$. Jarvis for editing the language. 